\title{
Tribunals in India - A need for Welfare state
}

\author{
Meenakshi $^{1^{*}}$ - Subhash Chandra Gupta ${ }^{1}$ \\ ${ }^{1}$ Department of law, H.N.B. Garhwal University (A Central University), B.G.R Campus Pauri, Uttarakhand- \\ India. 246001
}

*Corresponding author: meenakshinautiyalkukreti1992@gmail.com

Received: 16.11.2021; Revised: 17.12 2021; Accepted: 20.12.2021

(O) Society for Himalayan Action Research and Development

\begin{abstract}
Tribunals are an important mechanism for maintaining justice. Justice is the first and most important concept of any democratic country. Tribunals are the important part of our justice delivery plan and tribunalisation is wide concept and very helpful for providing social justice. In India the tribunal system developed by the constitutional amendments, legislation and by the judicial decision of our apex court. Tribunals are quasi-Judicial bodies and work according to the legal norms and principle of natural justice. The tribunal system is growing day by day with the development of the country. The main reason for the development of tribunals is democratic nature of the country, because a democratic country is more responsible for its citizens. Tribunals provide speedy, costless and quality justice which is our basic human right and a fundamental right. There is needed lot of work for development of tribunal system and make it more independent, efficient and responsible, due to which the main object of its establishment fulfilled to provide justice a proper justice. This article focused on the meaning of Tribunal, development of Tribunals and working different types of tribunals in India.
\end{abstract}

Keywords: Independence, Justice, Quasi-Judicial, Tribunals, Welfare State

\section{Introduction}

"Tribunals have certain characteristics which often give them advantages over the courts. These are cheapness, accessibility, freedom from technicality, expedition and expert knowledge of their particular subject". (Report of Franks Committee 1957)

India is a world's largest democratic country and also follows the concept of welfare state, due to the tribunal system developing day by day. This development is a need for this developing country. The main purpose of establishment of tribunals is to solve disputes speedily. It is a basic need of any democratic country to fulfil the requirements of its citizens and maintain the social order as well as justice in society. Justice is a very important concept in any welfare society but it has no meaning when we get it too late. It is very important for justice that we achieve it quickly and without any cost. Sometimes we lose justice by the unimportant reasons like long and time consuming and so costly procedures and sometimes some subjects need perfection so there is need of expertise and without these it is against the true meaning of justice and it is against our basic human right. Prof. Wade stated that- "The social legislation of the twentieth century demanded tribunals for purely administrative reasons; they could offer speedier, cheaper and more accessible justice, essential for the administration of welfare schemes involving large numbers of small claims. The process of Courts of law is elaborate, slow and costly.... Commissioners of customs and excise were given judicial powers more than three centuries ago. Tax tribunals were in fact established as far back as the 18th century." The concept of the Tribunal 
system originated from the Droit administration system of France, in this system there are two separate courts, one which deals with administrative disputes and one which deals with other matters. In England it was developed by the Franks committee report1957.

\section{Meaning of Tribunals}

By its purpose and its functioning Tribunals providing justice in any legal system. Basic purpose of establishment of tribunals is to provide proper or adequate justice to all. The general meaning of tribunal is the place of justice in Roman. In general, it is a synonym of court, but in practice the term tribunal used mainly some special courts which are established for the supplementary and a part of court, they are not proper courts, tribunals have some features of ordinary court, but some are different. The meaning of 'Tribunal' in Roman 'Tribune' which means 'a seat of magistrate'. In the year 1952 the Supreme court of India first time define the tribunals in the case of Durga Shankar Mehta v. Raghuraj Singh (AIR 1954 SC 520) "the expression 'tribunal' according to Article 136 does not mean something as 'Court' but includes within it, all adjudicating bodies, provided they are constituted by the State to exercise judicial powers as distinguished from discharging of administrative or legislative functions." In the case of Bharat Bank Ltd., Delhi v. Employees of the Bharat Bank Ltd., Delhi (AIR 1950 SC 188) "The Supreme Court held that the award of a Tribunal can be challenged under Article 136 of the Constitution if the Tribunal is the creature of Statute and observes the provisions of special Act and when it is vested with the functions of the Court or necessary trappings of the Court". At present time the work of the government is increasing day by day because it is the era of development, India is also a developing country and so it is very important with the development works that also maintain the social security because the development is for. So, it is the demand of society to establish a body which deals with social security as well as social justice. In India a separate body of government is established for solving disputes and providing justice which is known as Judiciary which covers the Supreme Court of India, High Court and other subordinate Court, the question arising hare when there is a special and separate body is available so why is need felt for establishments of tribunals?

\section{Reasons for establishment of tribunals}

- Provide speedy or fastest and cheapest (low cost) justice Tribunals provide speedy justice to all. Tribunals followed the principle of natural justice in the place of complex procedural rules, so parties do not face unnecessary burden. Tribunals provide justice without any cost or very low cost; in this welfare scheme of state some subjects require quick decisions and it is not possible by the ordinary court, so, it is very important in every 
society that justice should not depend on all these things because all these things break the true meaning of justice.

- Provide quality justice - It is not possible for the ordinary court to solve the technical issues easily. It is very important for the proper and quality justice that the technical matters are solved by its expert.

- Provide more accessible justiceTribunals provide speedy and cheapest justice so parties get the justice quickly and easily.

- The Tribunal reduced the unnecessary burden of ordinary court- Ordinary court facing the overburdened issues because they deal with almost every type of subject matters and tribunals worked as a branch of the judicial system.

Our traditional judicial system follows the technical procedural rule but in this welfare of the state the work of the state increases continuously and sometimes various emergency situations are raised and sometimes various complicated subject matter issues raised and it is not possible for our traditional judicial system to deal with all the subject matter and any situations. So, the demand for establishment of tribunals increased and various tribunals originated by the social legislation. Due to that at present time the word tribunal is a very known word. The words of Swarn Singh committee report which mentioned the importance of tribunals -'To reduce the mounting arrears in High Courts and to secure the speedy disposal of service matters, revenue matters and certain other matters of special importance in the context of the socio-economic development and progress, it is considered expedient to provide for administrative and other tribunals for dealing with such matters while preserving the jurisdiction of the Supreme Court in regard to such matters under article 136 of the Constitution.' So, we can say that Tribunalisation maintained the social and economic justice and secure some basic principle that is 'Justice for all', 'Speedy Justice', and 'Quality Justice'. "There were two main goals behind setting up the tribunals, one, it allows application of specialised subject knowledge, apart from judicial principles, in disputes on technical matters, and, two, it reduces the burden on the traditional court system. However, several tribunals are facing the same issues of high caseload and pendency" (News Brief, by Swarajya Staff).

\section{Nature of Tribunals}

Tribunals are the creation of legislation or statute and tribunals get all the power by the statute, these are established by the act of legislature and these bodies work quasijudicial functions but they are not a government department, tribunals are independent from the executive. They decide the disputes between two parties, tribunals follow the natural justice concept in the 
working of its, and tribunals are free to the procedural and evidential rule as ordinary court. They are oversighted by the judiciary, and they are also part of judicial review and tribunals are empowered by the statute. Tribunals solves the disputes as ordinary court but not empowered to do the interpretation of any law and statute. "Tribunal' is an administrative body established for the purpose of discharging quasi-judicial duties. An Administrative Tribunal is neither a Court nor an executive body. It stands somewhere midway between a Court and an administrative body. The exigencies of the situation proclaiming the enforcement of new rights in the wake of escalating State activities and furtherance of the demands of justice have led to the establishment of Tribunals" ( Kagzi, M.C.J). So, we can say that tribunals are not proper court, some fact distinct court and tribunals to each other. According to Abhishek Kumar Jha "They are not a court nor are they an executive body. Rather they are a mixture of both. They are judicial in the sense that the tribunals have to decide facts and apply them impartially, without considering executive policy. They are administrative because the reasons for preferring them to the ordinary courts of law are administrative reasons."

\section{Establishment of Tribunals in India}

"The increase in the number of statutory Tribunals mirrors the rise in State activities. Because the legislation has progressively bestowed benefits on individuals and subjected their everyday lives to propagating control and management, the scope for dispute between an individual and the State has emerged" (Elliott, Mark, Beatson, Jack, Matthews, Martin).

After independence India adopted its own legal system. The Indian constitution makes the provision for three basic organs of government that are -Legislature, Judiciary and Executive. As the principle of separation of power all three organs are separate from each other. India also adopted this principle, separation of power and distributing the legislative, judicial and executive or administrative power between the three organs separately. As India is a world's largest democratic country with this also a developing country, so it is not possible that India follows this principle (separation of power) strictly. Due to which we get to see many such examples which are contrary to the principle of separation of power, tribunal system is the example of this. But in this welfare of states era, we can't say that tribunals are the contrary of separation of power, because it is a need of time and circumstances, tribunals are seems as a part of executive in view but in the working of tribunals and purpose of establishment we can see that tribunals are separate from executive and they are close to judiciary. According to H.M. Seervai, "the development of administrative law in a welfare state has made administrative tribunals a necessity,"

India first tribunal established during 1941 Income Tax appellate Tribunal. This tribunal reduced the workload of courts due to various social, economic and political changes after 
the independence in India the need was felt for establishment of such types of tribunals. Administrative Reforms Commission - 1966, Wanchoo Committee - 1970, The High Courts' Arrears Committee Report - 1972, Law Commission in its 58th Report (1974) and Swaran Singh Committee Report 1976. There was no provision in the constitution for establishment of a tribunal but the word tribunal is known in the Article 136 and 227 which relates to the power of Judiciary over the Tribunals and other subordinate courts. After the Swaran Singh Committee's report the $42^{\text {nd }}$ Constitutional Amendment Act 1976 amended the constitution and added the part XIV A in the constitution, section 323A deals with the establishment of administrative tribunals for the center and state level and Article 323B relates to the Tribunals for other matters. After this amendment Parliament enacted a statute Administrative Tribunal Act 1985 for the purpose of Article 323A. 323B deals with tribunal for other matters.

\section{B. Tribunals for other matters}

(1) The appropriate Legislature may, by law, provide for the adjudication or trial by tribunals of any disputes, complaints, or offences with respect to all or any of the matters specified in clause (2) with respect to which such Legislature has power to make laws.

(2) The matters referred to in clause (1) are the following, namely:

(a) levy, assessment, collection and enforcement of any tax; (b) foreign exchange, import and export across customs frontiers;

(c) industrial and labour disputes;

(d) land reforms by way of acquisition by the State of any estate as defined in Article 31A or of any rights therein or the extinguishment or modification of any such rights or by way of ceiling on agricultural land or in any other way;

(e) ceiling on urban property;

(f) elections to either House of Parliament or the House or either House of the Legislature of a State, but excluding the matters referred to in Article 329 and Article 329A;

(g) production, procurement, supply and distribution of foodstuffs (including edible oilseeds and oils) and such other goods as the President may, by public notification, declare to be essential goods for the purpose of this article and control of prices of such goods;

(h) offences against laws with respect to any of the matters specified in sub clause (a) to $(\mathrm{g})$ and fees in respect of any of those matters;

(i) any matter incidental to any of the matters specified in sub clause (a) to (h)[Constitution of India]

\section{Working Number of Tribunals in India}

At present in India various types of Tribunals are working, for example Central Administrative Tribunal, State Administrative Tribunal, Labour Court, National Green Tribunal, Income Tax Appellate Tribunal, Railway Rates Tribunal, customs, excise and Service 
Tax Tribunal, Competition Appellate Tribunal and Securities Appellate Tribunal, National Company Law Tribunal, National Company Law Appellate Tribunal etc. all the Tribunals are established by the statute under the part $14 \mathrm{~A}$ of Indian Constitution.

\section{Center Administrative Tribunal and} State Administrative Tribunals- Center Administrative Tribunal and State Administrative Tribunal established by the Administrative Tribunal Act 1985 section 4 of the act empowered the centre government to establish Centre Administrative Tribunal and State Administrative Tribunal and Joint Administrative Tribunal. The purpose of establishment of the tribunal is to deal with recruitment and conditions in public services. At present Centre Administrative Tribunals has 17 Regular Benches and 21 Circuit Benches in the country. Tribunals solved the matters by the principle of natural justice. It is not bound the procedural and evidence law, but it has power of civil court for summoning, witnesses etc (Sedtion22 of Administrative Tribunal Act 1985). The parties appear before the tribunal personally or with the help of legal practitioners. section 14 provides its jurisdiction over the recruitment and all service matters of public servants and its jurisdiction extends over the all-India services, the central civil services, Civil post under the central and civilian employees of defence services. Section 17 of the act provides that the tribunal has power to punish for contempt as High Court.

\section{Company Law Tribunal and Company} Law Appellate Tribunal - Under section 408, of The Companies Act, 2013 the central government empowered to establish National Company Law Tribunal and section 410 empowered the Central government to establish Company Law Appellate Tribunal. Section 420 of the act gives the opportunity of right to hearing to the parties. Section 421 of the act give the provision of appeal, if any party is not satisfied by the order of tribunal it may to appeal to the Appellate Tribunal and if any party aggrieved of the order of Appellate Tribunal, they can file appeal on supreme court under section 423 of the act. Both tribunals are not bound by the provision of civil Procedure code they shall guide by the principle of natural justice, and, subject to the other provision of this act and both the tribunals shall be empowered to regulate their own procedure. For the purpose of summoning, production of document, receiving evidence on affidavits, issuing commissions for the examination of witnesses or documents, dismissing a representation for default of deciding it ex parte, and other matter which is prescribed both tribunals shall have the same powers as are civil court under the Civil Procedure Code1908 (Section 424 of The Companies Act 2013) Under section 425 both the tribunals have the same power in respect of contempt of themselves as the High court.

3. National Green Tribunal- The Parliament enacted a statute in 2010 namely The National Green Tribunal Act 2010 for the 
establishment of a National Green Tribunal in the country. The tribunal deals with the disputes relating to environmental protection and natural resources. The tribunal is not bound to procedural law and evidential law but it is bound to apply principles of natural justice in their working. The principal bench of the tribunal is in New Delhi and other benches are in Bhopal, Pune, Kolkata and Chennai.

4. Income Tax Appellate Tribunal- The Income Tax Appellate Tribunal is the first tribunal in India it is started in the year 1941 under the Direct Tax Act, after the independence The Income Tax Act 1961 makes the provision for establishment an Income Tax Appellate Tribunal for the purpose of Tax related disputes.at present it has 63 benches it covered almost all the cities.

\section{Railway Rates Tribunal- Indian Railway}

Rated Tribunal is established by the central government under the Indian Railways act, 1989. The tribunal is quasi-judicial by nature; it is not bound by the strict rule of procedure and evidence law but it has some power under the Civil Procedure Code, as civil court related to summoning, witnessing, evidence in affidavit etc. The tribunal has the power to hear complaints against the railway administration relating to unreasonable rates.

6. Customs, Excise and Service Tax Appellate Tribunal- The Tribunal was established in the year 1982. The tribunal was created for the hearing appeals under the Customs Act, 1962, Central Excise Act. 1944 and Finance Act 1994. The aggrieved party can file an appeal before the Supreme Court.

7. Competition Appellate Tribunal - The Competition (Amendment) Act 2007 amended the Competition Act 2002 and makes the provision for establishment a Competition Appellate Tribunal for the purpose of hear appeal of Competition Commission, Finance Act, 2017 makes the notification and provided that various Tribunals along with the Competition Appellate Tribunal should merged into National Company Law Appellate Tribunal. So, at present the Company Law Appellate Tribunal has the jurisdiction in related matters.

8. Securities Appellate Tribunal- the tribunal is established under the provisions of Securities and Exchange Board of India Act, 1992 for the purpose to hear appeals against the Securities and Exchange Board of India (SEBI).

9. Labour Court - The Labour Courts deal with the disputes related to the employers and employees under the provisions of Labour laws. the Industrial Dispute Act, 1947 makes the provision of Labour Court. According to Section 7 -(1) The appropriate Government may, by notification in the Official Gazette, constitute one or more Labour Courts for the adjudication of industrial disputes relating to any matter specified in the Second Schedule and for performing such other functions as may be assigned to them under this Act and other The Labour Laws. 


\section{Judicial review over the Tribunals}

Tribunals are the subordinate of Judiciary, because under Article 136 and Article 226 and 227 the Supreme Court and the High Court are empowered to control all the subordinate courts and also tribunals. The power of judicial review is the most important power of the judiciary for securing our legal framework which is established by our constitution.

In the case of S.P. Sampath Kumar v. UOI (1987 AIR 386, Supreme Court of India, December. 9, 1986) The Administrative Tribunal Act, 1985 was challenged on the ground of its constitutional validity and on the grounds that the Act excluded the jurisdiction of the High Court under article 226 and 227 and this act destroyed the concept of judicial review. The court upheld that the act is constitutional and a tribunal could be a substitute for the High Court. But in the case of L. Chandra Kumar v. UOI (AIR 1997

SC1125, Supreme Court of India, March 18, 1997) the apex court - Ahmadi, CJ held that"In view of the reasoning adopted by us, we hold that Clause 2(d) of Article 323A and Clause 3(d) of Article 323B, to the extent they exclude the jurisdiction of the High Courts and the Supreme Court under Articles 226/227 and 32 of the Constitution, are unconstitutional. Section 28 of the Act and the "exclusion of jurisdiction" clauses in all other legislations enacted under the aegis of Articles $323 \mathrm{~A}$ and 323B would, to the same extent, be unconstitutional. The jurisdiction conferred upon the High Courts under Articles 226/227 and upon the Supreme Court under Article 32 of the Constitution is part of the inviolable basic structure of our Constitution. While this jurisdiction cannot be ousted, other courts and Tribunals may perform a supplemental role in discharging the powers conferred by Articles 226/227 and 32 of the Constitution."

\section{Conclusion}

At present in this development era tribunals are playing a most important role in any welfare country. Tribunals are the quasijudicial bodies established by the statute; some tribunals are established for the specific purpose after the completion of the purpose they lost the existence and some tribunals are permanent. Tribunals are established by the various reasonable causes, so, it is necessary to provide tribunals more independence due to which the purpose of establishment became successful. Tribunals are not a court and also not a government department. The legislature makes it independence from the government department by statute. Some provisions of tribunals are still present which make a question of its independence like.... appointment process of members, terms of offices and composition of tribunal. The main purpose of establishment of tribunals is to provide speedy justice but at present tribunals are also facing the pendency and lack of resources which include Human resources, infrastructure and financial resources. Some time the fairness of tribunals is questioned on the basis of that tribunals does not follow the rule of natural justice fairly secondly the 
appointment of its member is not free from the indirect interfering of government. It is important that make all the tribunals free form the government department and makes the transparency and clearance in its working, in the year 2021 the government passed the ordinance The Tribunals Reforms (Rationalisation and Conditions of Service) ordinance, 2021 which is challenged Madras Bar Association on Supreme court of India, the Supreme Court makes the provision unconstitutional on the basis of inequality which is guaranteed in the article 14 of the constitution because there was a clear distinction between the civil servants and members of tribunals. After the questing the disputed provisions of the ordinance by the apex court the parliament enact a statute Tribunal Reforms Act 2021 and insert the same provision which is declared unconstitutional by the supreme court of India.

\section{References:}

Explained: The Tussle Between Centre And Supreme Court Over Tribunals (swarajyamag.com)

Abhishek Kumar Jha, National University of Study and Research in Law, Ranchi. ADMINISTRATIVE TRIBUNALS OF INDIA A Study in the light of decided cases.

Gupta Balram K, Administrative Tribunals and Judicial Review: a comment on 42nd amendment

Goel Shivam, Administrative Tribunal in India.
GOVERNMENT OF INDIA LAW COMMISSION OF INDIA, Report No.272 October, 2017, Assessment of Statutory Frameworks of Tribunals in India.

Aditya Kumar PRS Legislative Research Institute for Policy Research Studies July 24, 2021, The Tribunal System in India

Draft Speech for the use of on Hon'ble Union Minister for Law \& Justice All India Conference of the Central Administrative Tribunal Vigyan Bhawan, New Delhi

Takwani CK, Lectures on Administrative Law, E.B.C., Fourth Edition.

Kesari UPD.Administrative Law, Central Law Publication, 18th edition 2010

Joshi KC, An Introduction to Administrative Law, Central Law Publication, 1st edition 2006

Sathe SP Administrative Law, LexisNexis Butterworths 7th edition, 2004 reprint 2006.

Jain MP, Jain SN Principles of Administrative Law, LexisNexis 6th Edition, Updated Edition 2013.

Wade HWR, Forsyth CF Administrative Law, 9th Edition Indian Edition.

Seervai HM Constitutional Law of India, Universal Law Publishing Co. Pvt.Ltd., 4th Edition, Silver Jubilee Edition

Kagzi MCJ The Indian Administrative Law, Metropolitan Book Co. Pvt. Ltd., Delhi, 3rd edition, 1973 
Elliott Mark, Beatson Jack, Matthews, Martin, Administrative Law: Text and Materials, Oxford University Press, New York, 3rd edition, 2005 at p. 679.

Durga Shankar Mehta v. Raghuraj Singh, AIR 1954 SC 520.

Bharat Bank Ltd., Delhi v. Employees of the Bharat Bank Ltd., Delhi, AIR 1950 SC 188

S P Sampath Kumar Etc. v. Union of India and Ors., 1987 AIR 386, Supreme Court of India, December. 9, 1986

L Chandra Kumar v. Union of India and Ors., AIR 1997 SC1125, Supreme Court of India, March 18, 1997. 